\title{
THE TEAMSTER JOINT GRIEVANCE COMMITTEE AND NLRB DEFERRAL POLIGY: A FAILURE TO PROTEGT THE INDIVIDUAL EMPLOYEE'S STATUTORY RIGHTS
}

\author{
Gregory E. ZIMMERMAN ${ }^{\dagger}$
}

A Teamster driver, exhausted after several days of long hauls, concerned with her safety, and cognizant of Department of Transportation regulations that prohibit a carrier from requiring an employee to drive while dangerously ill or fatigued, ${ }^{1}$ refuses a work assignment. ${ }^{2}$ The driver is subsequently discharged and files a grievance ${ }^{3}$ under the applicable Teamster collective bargaining agreement. ${ }^{4}$ She charges both that her dismissal violated the contract ${ }^{5}$ and that her dismissal was the

† B.A., Dickinson College, 1983; J.D. Candidate 1986, University of Pennsylvania. The author wrote this Comment while a student at the University of Pennsylvania Law School.

1 The Department of Transportation regulation states that

[n]o driver shall operate a motor vehicle, and a motor carrier shall not require or permit a driver to operate a motor vehicle, while the driver's ability or alertness is so impaired, or so likely to become impaired, through fatigue, illness, or any other cause, as to make it unsafe for him to begin or continue to operate the motor vehicle.

49 C.F.R. $\S 392.3$ (1983).

2 The hypothetical situation presented is loosely based on Finn v. Yellow Freight Sys., No. 83-1769 (3d Cir. Oct. 29, 1984). See Brief of Appellant at 3-6, Finn v. Yellow Freight Sys., No. 83-1769 (3d Cir. Oct. 29, 1984).

3 The grievance process provides a forum for resolution of disputes arising over the implementation of the collective bargaining agreement in existence between a union and an employer. As Professor Robert Gorman notes:

Complaints of contract breach . . . are typically brought, by the union or the individual grievant, to a low-level supervisor in the first instance, and if unresolved to higher levels of supervision. If the dispute remains unresolved at the highest level of confrontation between union officials . . . and company officials ... it will be submitted to an arbitrator, voluntarily selected by the parties to the contract.

R. GoRman, Basic Text on Labor LAw: Unionization and Collective BarGAINING 541-42 (1976).

In the teamster system, the framework for grievance processing is set forth in the local supplemental agreements which expand on the master agreements. See United Parcel Service Teamsters Local 623 Supplemental Agreement art. 41, § 2 (covering May 1, 1982 through June 1, 1985) ("A grievance is hereby jointly defined to be any controversy, complaint, misunderstanding or dispute arising as to interpretation, application or observance of any of the provisions of this Agreement or Supplements hereto.") [on file at the University of Pennsylvania Law Review] [hereinafter cited as Supplemental Agreement].

s See, e.g., National Master United Parcel Agreement: "Under no circumstances will an employee be required or assigned to engage in any activity involving dangerous 
result of pressure by the union on her employer because of her membership in Teamsters for a Democratic Union (TDU). ${ }^{6}$

In accordance with the local Teamster grievance procedure, ${ }^{7}$ the grievance is submitted to a Teamster joint grievance committee, an adjudicatory body composed of equal numbers of management and labor representatives. ${ }^{8}$ After a brief hearing, the committee denies the grievance upon a finding that there was "just cause" for the dismissal, as required by the collective bargaining agreement. ${ }^{9}$ The committee's "opinion" consists of the curt statement, "Based on the facts of the case, the grievance is denied." 10 Convinced that her membership in TDU

conditions of work or danger to a person or property or in violation of a government regulation relating to safety of person or equipment." National Master United Parcel Service Agreement, art. 18, $\S 1$ (covering May 1, 1982 through June 1, 1985) [on file at University of Pennsylvania Law Review] [hereinafter cited as Master Agreement].

${ }^{\circ}$ TDU is a "national organization of rank and file Teamsters dedicated to reforming the Teamsters Union and making it more responsive to its members." Brief of Appellant at 4, Finn v. Yellow Freight Sys., No. 83-1769 (3d Cir. Oct. 29, 1984).

7 See, e.g., Supplemental Agreement, supra note 4, art. 41, § 2. Under the Local 623 Agreement, grievance procedures may only be invoked by authorized union representatives. See id. An employee is required to report grievances to her shop steward in writing within five working days. The steward then submits the grievance to the supervisor for adjustment and a meeting date is arranged. See id. $\S 2(a)$. If there is no agreement, the steward must report the matter to the union who "shall attempt to adjust the same with the Employer within five (5) days." See id. § 2(b). If no decision is reached or no settlement agreed upon, and if the grievance relates to the supplemental agreement and not to the interpretation or application of the master agreement, the matter is then submitted within ten days to the Atlantic Area Parcel Grievance Committee (AAPGC). See id. § 2(c)(1). All discharge cases, however, are heard monthly on a designated date by the AAPGC. See id. $\S 3(\mathrm{~g})$. In discharge cases, an impartial arbitrator sits along with union and management representatives in order to render a deciding vote should the committee split evenly. See id.

8 Joint grievance committees are provided for in Teamster collective bargaining agreements. See, e.g., Supplemental Agreement, supra note 4, art. 41, § 3.

-The "just cause" standard protects the employee from discharge at the whim of the employer. Again, the United Parcel Service Teamsters Local 623 Supplemental Agreement is illustrative:

The Employer shall not discharge nor suspend any employee without just cause until the case has been discussed with the Business Agent in person, where practical, except where the provisions of this Article provide for discharge, but in respect to suspension or discharge shall give at least one warning notice of the complaint against such employee to the employee, in writing ....

Supplemental Agreement, supra note 4, art. 43. Allowable causes for discharge are a mandatory subject of bargaining. See R. Gorman, supra note 3, at 504.

${ }_{10}$ There are no recorded decisions in Teamster joint grievance committee proceedings. Petition for a Writ of Certiorari at 10, Early v. Eastern Transfer, 699 F.2d 552 (1st Cir.), cert.denied, 464 U.S. 824 (1983). Generally, efficiency is the primary reason for the dearth of written opinions. The committees hear a staggering number of cases, as many as thirty in one day. See infra note 163 and accompanying text. It is obvious that agreements are more easily reached without the complications of "agreeing" to a written rationale for the decision. 
affected the impartiality of the joint committee, the employee files an unfair labor practice complaint with the National Labor Relations Board (NLRB) claiming that the employer violated section 8(a)(3) of the National Labor Relations Act (NLRA) ${ }^{11}$ by discouraging her membership in a labor organization.

The NLRB dismisses the complaint, following its long-standing "deferral" policy ${ }^{12}$ of refusing to consider complaints that have been at least partially the subject of an arbitrator's decision. As a result, the joint grievance committee's denial of the claim is the final judgment in the case, and the discharge remains in effect. ${ }^{13}$

This hypothetical scenario raises many questions about the propriety of the Board's policy of deferring to arbitration, particularly when the arbitral body receiving the deference is not a neutral arbitrator but rather a joint grievance committee. The Board's deferral policy must be considered in light of the NLRA, the statute that provides the framework for the American labor relations system. Section 7 evinces the fundamental aims of the Act:

Employees shall have the right to self-organization, to form, join, or assist labor organizations, to bargain collectively through representatives of their own choosing, and to engage in other concerted activities for the purpose of collective bargaining or other mutual aid or protection, and shall also have the right to refrain from any or all of such activities except to the extent that such right may be affected by an agreement requiring membership in a labor organization as a condition of employment as authorized in section 8(a)(3) of this title. ${ }^{14}$

11 National Labor Relations [Wagner] Act § 8(a)(3), 29 U.S.C. § 158(a)(3) (1982). Citations to the NLRA include references to its amendments. Board:

12 "Deferral policy," while technically inaccurate, is the term of art used by the

"Deferral" means postponement; e.g., postponement of a Board decision until after an arbitrator has decided the case . . . . [T] The issue [however] in this area of labor law is whether the Board will give deference to the arbitrator's decision on a statutory issue in a particular case. Thus, "deference policy" would be more accurate, but "deferral policy" is the accepted term of art.

Comment, Judicial Review and the Trend Toward More Stringent NLRB Standards on Arbitral Deferrals, 129 U. PA. L. REv. 738, 739 n.5 (1981).

13 See, e.g., Carolina Freight Carriers Corp., No. JD-91-84, slip op. at 7 (NLRB Div. of Judges, Socoloff, A.L.J., Mar. 12, 1984) (dismissing complaint concerning suspension of employees); infra text accompanying notes 131-49.

14 National Labor Relations [Wagner] Act § 7, 29 U.S.C. § 157 (1982). Section 8(a)(1) makes it an unfair labor practice for an employer to "interfere with, restrain, or coerce employees in the exercise of the rights guaranteed in section 7." Id. at $\S 8(\mathrm{a})(1)$, 
Two types of rights are provided and protected by the NLRA, individual rights and collective rights. The individual's right to engage in union membership, free from discrimination by an employer or another union, is established in sections $8(a)(1), 8(a)(3), 8(b)(1)(A)$, and $8(\mathrm{~b})(2),{ }^{15}$ while sections $8(a)(5)$ and $8(b)(3)$, which deal with the aggregate relationship of the employees with the employer, protect collective rights by mandating collective bargaining. ${ }^{16}$

In the hypothetical situation framed at the outset of this Comment, tensions between collective rights and individual rights are apparent. The NLRB is responsible for enforcing the Act through the adjudication of unfair labor practice claims. ${ }^{17}$ It is questionable, however, whether the Board is fulfilling its task when it defers to a Teamster joint grievance committee. This Comment considers the impact of the

29 U.S.C. $\S 158(a)(1)$ (1982). Section $8(b)(1)(A)$ makes it an unfair labor practice for the union to so act in restraint of the employees' section 7 rights. Id. $\S 8(\mathrm{~b})(1)(\mathrm{A}), 29$ U.S.C. § 158(b)(1) (1982).

16 National Labor Relations [Wagner] Act $\S \S 8(\mathrm{a})(1), 8(\mathrm{a})(3), 8(\mathrm{~b})(1)(\mathrm{A})$, $8(\mathrm{~b})(2), 29$ U.S.C. $\$ \S 158(\mathrm{a})(1), 158(\mathrm{a})(3), 158(\mathrm{~b})(1)(\mathrm{A}), 158(\mathrm{~b})(2)$ (1982). Section $8(a)(1)$ is a catch-all provision, making it an unfair labor practice for an employer "to interfere with, restrain, or coerce employees in the exercise of the rights guaranteed in Section 7. 29 U.S.C. $\S 158(a)(1)$. Section $8(a)(3)$ provides that employers may not discriminate "in regard to hire or tenure of employment or any term or condition of employment to encourage or discourage membership in any labor organization." 29 U.S.C. $\S 158(a)(3)$. Section $8(b)(1)$ (a) makes it an unfair labor practice for a union to "restrain or coerce . . employees in the exercise of the rights guaranteed in section 7 . . . 29 U.S.C. 158(b)(1). Section 8(b)(2) prohibits a union from causing an employer to discriminate in violation of section $8(a)(3)$ and from discriminating itself "against an employee with respect to whom membership in such organization has been denied or terminated on some ground other than his failure to tender the periodic dues and the initiation fees." National Labor Relations [Wagner] Act $\S 8(b)(2), 29$ U.S.C. $\S 158(b)(2)(1982)$.

${ }_{16}$ National Labor Relations [Wagner] Act $\S \S 8(a)(5), 8(b)(3), 29$ U.S.C. $\S \S 158(a)(5), 158(b)(3)(1982)$. Section $8(a)(5)$ makes it an unfair labor practice for the employer to "refuse to bargain collectively with the representatives of his employces." 29 U.S.C. $\S 158(\mathrm{a})(5)$. Section $8(\mathrm{~b})(3)$ applies the same provision to the union. 29 U.S.C. $\S 158(\mathrm{~b})(3)$. (1982).

17 See National Labor Relations [Wagner] Act $\S 10(a), 29$ U.S.C. § 160(a)

Inherent in any consideration of substantive issues in labor law are tensions that reflect underlying interests and philosophies in our democratic society. As Professors Summers, Wellington and Hyde note, "Here power is shared between the law and private institutions-unions and management-with the law enhancing, structuring and curbing the power of these private institutions. We, therefore, constantly address the general problem of defining the relative role of public and private processes in ordering a democratic society." C. Summers, H. WeLlington \& A. HydE, LABOR LAw: Cases and Materials xxiii (2d ed. 1982) [hereinafter cited as G. Summers]. The relationship between the Teamster joint grievance committee system and the Board reflects this tension, innate in American labor law, between public and private regulation. It is essentially a political and philosophical quandary. Just how much power one is prepared to allow the Teamster committees to exercise depends upon one's conception of what the Act requires the Board to protect and to what extent. 
NLRB's deferral to the Teamster's "arbitration"18 process on the rights of the individual employee. First, the Comment discusses the form and procedure of the Teamster joint grievance committee system. Second, it analyzes the development of the Board's deferral policy with an eye toward the Board's philosophy regarding individual and collective rights. Third, it questions the advisability of deference to joint committee decisions.

The Comment concludes that, in the Teamster context, the Board's deferral policy must distinguish between grievances involving individual rights and those involving collective rights. In cases involving alleged violations of collective rights, deferral is a commendable way of effectuating the Supreme Court's conception of arbitration as an extension of the collective bargaining system, ${ }^{19}$ since the joint grievance committees allow management and the union to negotiate over contract interpretation. Conversely, in individual rights cases, the Teamster system does not adequately protect the individual from management or union discrimination. In effect, it mandates negotiation over whether the statute has been violated and places the alleged violators in the position of deciding the outcome of the grievance. To resolve this problem, the Comment suggests that the Board should refuse to defer in cases of alleged unfair labor practices between the individual employee and either her employer or her union. By deferring in cases involving collective rights and adjudicating cases involving individual rights, the Board will at once realize the goals both of private, contractual dispute resolution and protection of individual employee rights.

\section{The Teamster Joint Grievance Commitee System}

The joint grievance committee is an established institution within the Teamsters Union, initially adopted as a contractual dispute-resolution system by the Central States Drivers Council of the Teamsters in 1938. ${ }^{20}$ There is no specific committee form or procedure that obtains

18 The Board, without setting forth any basis for its conclusion, has termed the Teamster joint grievance committee system "arbitration" and has accorded it all the deference generally accorded neutral arbitrators. Analysis casts doubt on the propriety of treating the Teamster committees as neutral arbitrators. See infra notes 127-73 and accompanying text.

10 The Court espoused this conception of arbitration in a series of cases, known collectively as the Steelworker's Trilogy. United Steelworkers of Am. v. Enterprise Wheel \& Car Corp., 363 U.S. 593 (1960); United Steelworkers of Am. v. Warrior \& Gulf Navigation Co., 363 U.S. 574 (1960); United Steelworkers of Am. v. American Mfg. Co., 363 U.S. 564 (1960).

${ }_{20}$ See Azoff, Joint Committees as an Alternative Form of Arbitration Under the NLRA, 47 Tul. L. REv. 325, 329 (1973). 
throughout the union; rather the committees are found in "many sizes, shapes and varieties."21 Significantly, some committees allow economic recourse $^{22}$ if the joint committee "deadlocks"23 at the last stage of the grievance procedure, while others provide for arbitration by a neutral if no majority decision can be reached. ${ }^{24}$

Although the Teamster committees are not uniform, they nonetheless share several basic traits. The committees are established under the collective bargaining agreement and are composed of equal numbers of management and union representatives. ${ }^{25}$ There are usually no neutrals present at the committee hearings. Local union officials and company representatives are not permitted to sit on cases in which their respective organizations are involved. ${ }^{26}$ Instead, representatives of the parties involved in the dispute present and advocate their positions with respect to the grievance. ${ }^{27}$ The panel makes its decision immediately after the conclusion of the hearing. ${ }^{28}$ Typically, the committees meet on a regular basis with a firmly set agenda, determined in advance. ${ }^{29}$ The collective bargaining agreements, however, establish no more than a loosely

${ }_{21}$ Miller, Teamster Joint Grievance Committees: The Legal Equivalent of Arbitration, 37 Proc. Nat'l Acad. ARb. [ARBItration 1984] 118, 118 (1984).

${ }^{22}$ Economic force by the union is typically asserted through a strike or a boycott. See C. SUMmERS, supra note 17 , at 402 . It seems incongruous to define the joint grievance committee proceedings as arbitration when a failure to agree at the highest level leads not to arbitration by a neutral but to economic action. See Feller, A General Theory of the Collective Bargaining Agreement, 61 CALIF. L. REv. 663, 838 (1973). The most sophisticated and indeed the largest Teamster collective bargaining agreement, the National Master Freight Agreement, provides that, should the national committee fail to reach a majority decision, "either party shall be entitled to all lawful economic recourse to support its position in the matter." Miller, supra note 21, at 121. The National Master United Parcel Service Agreement similarly allows work stoppages, slowdowns, walkouts or lockouts should the National Grievance Committee fail to come to a majority decision over a question of the Agreement's interpretation. Master Agreement, supra note 5, art. 8, § 2.

28 "Deadlock" is the term of art used to describe the situation wherein there is no majority of committee members in support of one side or the other. See, e.g., Sine v. Local No. 992 Int'l Bhd. of Teamsters, 644 F.2d 997, 999 n.4 (4th Cir.), cert. denied, 454 U.S. 965 (1981); Nabisco, Inc. v. NLRB, 479 F.2d 770 (2d Gir. 1973). "Deadlock" in this context means that management has voted to deny the grievance while labor has voted to uphold it.

24 Miller, supra note 21 , at 118.

25 Id. at 119.

${ }^{26}$ See, e.g., Rules of Procedure, Eastern Conference Joint Area Committee, art. IV, \& 2 (adopted pursuant to arts. 7 \& 8 of the National Master Freight Agreement, July 1, 1973 to Mar. 31, 1976) [hereinafter cited as Rules of Procedure] [on file at the University of Pennsylvania Law Review].

27 Miller, supra note 21, at 119.

${ }^{28}$ See id. at 2; see also, Rules of Procedure, supra note 26, art. V, $\S 1$.

29 See Miller, supra note 21, at 119; see also Rules of Procedure, supra note 26, art. III, $\S \S 1 \& 2$ (the Eastern Conference Joint Committee met quarterly with the docket set twelve days in advance). 
defined framework for the actual workings of the committee system. ${ }^{30}$ Most of the procedural rules are established by each of the committees at the various levels of the Teamsters Union. ${ }^{31}$

Prior to the hearing, it is frequently the case-and indeed expected-that the employer and the union engaged in the grievance will contact members of the committee to discuss the case. ${ }^{32}$ Members may ask questions or make suggestions indicating their disposition as to the merits of the grievance. ${ }^{33}$ The parties may choose to rely on such comments to focus their arguments or seek a settlement.

At the hearing, the parties present witnesses and testimony as they desire. ${ }^{34}$ The employee, although represented by the union's business agent, is generally permitted to present her own evidence and witnesses, but she may not be represented by anyone other than the local union representative. $^{35}$ Any member of the committee may observe the hearing, but only members selected for that particular panel are permitted to confer or vote. ${ }^{36}$ Argument may be cut off by a majority vote after all factual information is presented. ${ }^{37}$ Decisions are normally reached immediately after each case and either given to the parties at that time or mailed to them later..$^{38}$ Few reasons, if any, are ever given for the joint committee's decision. Typically, the only recorded "opinion" consists of "grievance denied" or "grievance forwarded."39 Majority decisions are final and binding, and many collective bargaining agreements require that the parties sign a form in advance of the hearing acknowledging that fact. ${ }^{40} \mathrm{~A}$ deadlocked vote results in the forwarding of the grievance

so See, e.g., Supplemental Agreement, supra note 4, art. 41, § 3 .

32 See, e.g., Rules of Procedure, supra note 26, art. IV, §8F 2.

32 See Davis v. Ryder Truck Lines, 97 Lab. Cas. (CGH) II 10,027, 17,103, 113 L.R.R.M. 2072, 2075 (S.D. Ohio, Dec. 7, 1982) ("The overwhelming weight of the evidence established that pre-hearing conversations . . . are customary procedures under the National Master Freight Agreement.").

ss See Deposition of John W. Shepard at 14 (Sept. 24, 1982), Davis v. Ryder Truck Lines, 97 Lab. Gas. (CCH) I 10,027, 113 L.R.R.M. (BNA) 2072 (S.D. Ohio, 1982). Shepard notes that during pre-hearing discussions, "grievance panel members . . . are free to make recommendations or suggestions or be the devil's advocate in discussing the case." Id.

s4 See, e.g., Rules of Procedure, supra note 26, art. V, § 3.

ss See, e.g., Central States Area Local Cartage Supplemental Agreement, art. 44, $\S 6$ (1977) [on file at the University of Pennsylvania Law Review].

${ }^{36}$ See, e.g., Rules of Procedure, supra note 26 , art. V, $\S 3$. Nonetheless, the potential for psychological pressure due to the presence of these "nonparticipating" members is significant.

s7 See id. art. V, § 1.

${ }^{38} I d$.

39 See, e.g., Sine v. Local 992, Internat'l Bhd. of Teamsters, 664 F.2d 997, 1000 \& n.6 (4th Cir.), cert. denied, 454 U.S. 965 (1981); Miller, supra note 21, at 126. But see NLRB v. Wolff \& Munier, Inc., 747 F.2d 156, 159 (3d Cir. 1984).

${ }^{10}$ The Eastern Conference rules, for example, provide: 
to the next highest level of the process. ${ }^{11}$ Within the system, most of the Teamster joint committees are organized hierarchically from local to state, area, and national committees. ${ }^{42}$ The national committee is usually an appellate body. Thus, important factual findings relevant to the validity of the grievance are made at the lower levels. ${ }^{43}$

The Teamsters present virtually every grievance to a joint committee for resolution. Unlike other unions that exercise their discretion by refusing to process spurious claims through arbitration, the Teamsters put all grievances through the first committee level and union panel representatives simply vote to deny those they feel are unmeritorious. ${ }^{44}$ Thus the employee, having received at least a first level grievance hearing, cannot complain that the union refused to act on her dispute. More importantly, the decision of the joint committee, however poorly recorded, provides the Board, in virtually every case, with an "arbitration" decision to which it may defer.
A uniform Joint Submission Form setting forth an agreement to submit the grievance to the Committee for final and binding decision without fur- ther recourse to any other tribunal shall be signed by the parties involved and submitted ... prior to the grievance being heard. The Co-Chairman may refuse to hear any case in which a party refuses to sign the Submis- sion Form, but if the case is heard, it shall be final and binding on all parties.

Rules of Procedure, supra note 26, art. IV, $\S 5$.

41 See Miller, supra note 21, at 120-21.

42 See id.; Feller, supra note 22, at 836.

43 As the United Parcel Service Agreement provides: "All grievances involving questions of fact, as contrasted to questions of interpretation, shall be resolved pursuant to the provisions relating to the Local, State and Area grievance procedures set forth in the applicable Supplements to this Agreement." Master Agreement, supra note 5, art. $8, \S 6$.

44 See Brief of Plaintiffs-Appellants at 17, Barrentine v. Arkansas-Best Freight Sys., 615 F.2d 1194 (8th Gir. 1980), rev'd, 450 U.S. 728 (1981). Indeed, in many respects

[t]he genius of the Teamster procedure is that the union presents practically every grievance to a joint committee. Accordingly, discretion to sift out unmeritorious grievances is exercised not by the local business agent who "presents" the grievance, but by the union representatives .... [W]henever a member's grievance is denied, the Union representatives must have voted to deny the grievance; had they voted to sustain it, the committee would have deadlocked ....

Petition For A Writ of Certiorari at 9-10, Early v. Eastern Transfer, 699 F.2d 552 (1st Cir.), cert. denied, 464 U.S. 824 (1983) [hereinafter cited as Petition]. 


\section{The Development of NLRB Deferral Policy: AN OVERVIEW}

\section{A. Congress and the Supreme Court}

In 1947 Congress enacted the Taft-Hartley $\mathrm{Act}^{45}$ and thereby adopted a policy of supporting private dispute resolution in labor-management relations. ${ }^{46}$ Unions and management thereafter began including arbitration clauses in their agreements, whereby they agreed to resolve disputes over contract interpretation in arbitration rather than through economic forces. As a result, collective bargaining agreements that contain arbitration clauses are more than contracts: "each is an attempt to create an instrument of industrial self-government." "7z

Following Congress' endorsement of private dispute resolution, the Supreme Court delineated the courts' role in the arbitration process. In the seminal case, Textile Workers Union v. Lincoln Mills, ${ }^{48}$ the Court held that section 301(a) of the Taft-Hartley Act" "authorizes federal courts to fashion a body of federal law for the enforcement of these collective bargaining agreements and includes within that federal law specific performance of promises to arbitrate grievances under collective bargaining agreements." workers Trilogy, ${ }^{51}$ the Supreme Court further endorsed the national policy favoring grievance arbitration. In United Steelworkers v. War(1982).

15 Labor Management Relations [Taft-Hartley] Act, 29 U.S.C. $\$ \S 141-97$

16 Section 203(d) states: "Final adjustment by a method agreed upon by the parties is hereby declared to be the desirable method for settlement of grievance disputes arising over the application or interpretation of an existing collective bargaining agreement." Labor Management Relations [Taft-Hartley] Act § 203(d), 29 U.S.C. $\S 173(d)(1982)$.

17 Azoff, supra note 20, at 325 (citing Schulman, Reason, Contract, and Law in Labor Relations, 68 HaRv. L. Rev. 999, 1004 (1955)).

48353 U.S. 448 (1957).

19 Labor Management Relations [Taft-Hartley] Act $\S 301(a), 29$ U.S.C. $\S$ 185(a) (1982). Section 301(a) states:

Suits for violation of contracts between an employer and a labor organization representing employees in an industry affecting commerce as defined in this Act, or between any such labor organizations, may be brought in any district court of the United States having jurisdiction of the parties, without respect to the amount in controversy or without regard to the citizenship of the parties.

so Textile Workers Union v. Lincoln Mills, 353 U.S. at 451. See R. GormaN, supra note 3 , at 544-45.

81 United Steelworkers of Am. v. Enterprise Wheel \& Car Corp., 363 U.S. 593 (1960); United Steelworkers of Am. v. Warrior \& Gulf Navigation Co., 363 U.S. 574 (1960); United Steelworkers of Am. v. American Mfg. Co., 363 U.S. 564 (1960). 
rior $\mathcal{E}$ Gulf Navigation Co., ${ }^{62}$ Justice Douglas, writing for the majority, enthusiastically embraced the arbitration process and noted that grievance machinery established by a collective bargaining agreement is "at the very heart of . . . industrial self-government." "As "Arbitration," he continued, "is the means of solving the unforeseeable by molding a system of private law for all the problems which may arise and to provide for their solution in a way which will generally accord with the variant needs and desires of the parties."

\section{B. The National Labor Relations Board}

The Board is charged with the difficult task of adjudicating alleged violations of the NLRA, ${ }^{\text {s5 }}$ while arbitration is the favored system for contractual dispute resolution. ${ }^{\text {sB }}$ Actual cases, however, rarely present situations that fall squarely into the category of "contract interpretation" on the one hand, or "statutory interpretation" on the other. As Professor Gorman has noted, "A single transaction, involving an employer, its employees and their union, may give rise to two kinds of claims: one for breach of contract under the parties' collective bargaining agreement, and the other for application of the provisions of the National Labor Relations Act." ${ }^{\text {"sz }}$ Because of the difficulty in separating the two types of claims, and the Board's concern with the overlap of resources in having the NLRB and the arbitrator deciding parallel issues, the Board has consistently followed a policy of deferring to arbitration. ${ }^{88}$

s2 363 U.S. 574 (1960).

${ }^{83}$ Id. at 581 .

s4 Id.

so The Board is responsible for preventing any person from engaging in an unfair labor practice as defined in Section 8 of the Act. National Labor Relations [Wagner] Act $\S 10(a), 29$ U.S.C. § 160(a) (1982).

${ }^{8 B}$ See supra notes $45-46$ and accompanying text.

${ }^{67} \mathrm{R}$. GoRman, supra note 3, at 729.

58 The roots of the Board's deferral policy can be traced to a series of cases. See, e.g., NLRB v. Walt Disney Prods., 146 F.2d 44, 49 (9th Cir. 1944), cert. denied, 324 U.S. 877 (1945) (Board deferring to arbitrator's conclusion that Walt Disney discriminated against employee because of employee's union activity); Monsanto Chem. Co., 97 N.L.R.B. 517, 520 (1951), enforced, 205 F.2d 763 (8th Cir. 1953) (Board ruled that it was not bound by law to arbitrator's award because the case involved the interpretation of a statute).

For criticism and discussion of deferral policy, see Finston, The Board's Role in the Arbitral Process, 32 LAB. L.J. 799 (1981); Novack, Cutting Back on Collyer: The First Step in the Right Direction, 28 LAB. L.J. 785 (1977); Simon-Rose, Deferral Under Collyer by the NLRB of Section 8(a)(3) Cases, 27 LAB L.J. 201 (1976); Note, NLRB Deferral to Arbitration: The Evolution of the Spielberg Doctrine, 23 WM. \& MARY L. REv. 291 (1981) [hereinafter cited as Note, Evolution of the Spielberg Doctrine]; Note, The NLRB and Deference to Arbitration, 77 Y ALE L.J. 1191 (1968). 
There are two branches of the Board's deferral policy. ${ }^{59}$ Both are founded on the premise that activity forming the basis for an unfair labor practice charge is covered by both the Act and the applicable collective bargaining agreement. ${ }^{60}$ The first branch of deferral, established in Spielberg Manufacturing Co., ${ }^{61}$ represents complete deferral to the arbitral process. At issue in Spielberg was an employer's refusal to reinstate workers dismissed for conduct allegedly engaged in during a strike. $^{62}$ The strike settlement required that the union and employer arbitrate the issue of reinstatement; the arbitration panel held that the employer need not reinstate the employees. The employees subsequently sought relief before the NLRB, claiming a violation of their $8(a)(3)^{63}$ right to participate in a labor organization free from threat of discharge.

Noting that the arbitration award was not "at odds with the statute" and that all parties had "acquiesced in the arbitration proceeding," ${ }^{\text {"6s }}$ the Board deferred to the arbitration panel's decision. ${ }^{86}$ In so doing, the Board established the criteria that have formed the backbone of its deferral policy. In cases involving issues previously decided by an arbitrator, the Board will defer if "the proceedings appear to have been fair and regular, all parties had agreed to be bound, and the decision of the arbitration panel is not clearly repugnant to the purposes and policies of the Act." ${ }^{\text {"ez }}$ According to the Board, if this three-pronged test is met, the "desirable objective of encouraging the voluntary settlement of labor disputes will best be served by our recognition of the arbitrator's award."

The Spielberg opinion offers little to support its result. The Board cited no authority to support its conclusion that deferral was appropriate, and explained neither how the criteria for deferral were developed

s9 See Finston, supra note 58, at 799; Comment, supra note 12, at 739. See generally Note, Evolution of the Spielberg Doctrine, supra note 58.

60 For example, an employer is charged with making unilateral changes in wages in violation of sections $8(\mathrm{a})(1)$ and $8(\mathrm{a})(5)$ of the Act. National Labor Relations [Wagner] Act § 8(a)(1), (5), 29 U.S.C. § 158(a)(1), (5) (1982). In addition to the unfair labor question charge, there is a question about the interpretation of the parties' collective bargaining agreement: does a management prerogatives clause contained therein allow the employer to make such unilateral wage changes?

-1 112 N.L.R.B. 1080 (1955).

C2 Id. at 1081 .

os Id., referring to National Labor Relations [Wagner] Act $\S 8(\mathrm{a})(3), 29$ U.S.C. $\S 158(a)(3)(1982)$.

of Spielberg, 112 N.L.R.B. at 1082.

os Id.

os Id.

or Id.

es Id. 
nor how the criteria would protect section 7 rights. In fact, the Board never mentioned section 7 rights, but rather focused on "the desirable objective of encouraging the voluntary settlement of labor disputes." Given the Board's lack of analysis in Spielberg, one can only speculate about why the Board decided to exercise its discretion to defer. ${ }^{70}$ It is likely that the Board wanted to encourage arbitration for the same reasons advanced by the Supreme Court in the Steelworkers Trilogy: to encourage voluntary settlement of disputes ${ }^{71}$ and to rely on the knowledge of the law of the shop possessed by arbitrators. ${ }^{72}$

These considerations may be appropriate in a collective rights dispute where the union can be expected to represent adequately its own collective interests. In an individual rights dispute, however, the union may not have equivalent incentives to protect the aggrieved individual's rights, and thus there exists the risk that individual rights will be sacrificed to the promotion of the Steelworkers Trilogy goals of settlement and arbitral expertise. Additionally, courts, not arbitrators, have expertise in the protection of individual rights. ${ }^{73}$

The Board's policy of deferring in disputes involving the NLRA and those involving a contract is not required by any law. ${ }^{74}$ Spielberg,

$\therefore$ Id.

70 Deferral is an exercise of the Board's discretionary power to administer, develop, and enforce national labor policy. While Congress and the courts have provided general policy guidelines for the NLRB to follow (express support for arbitration as a dispute resolution process is one example), the guidelines are often devoid of specific rules for the implementation of the policy. Hence, the Board's "back and forth wanderings . . . in the wilderness of deferral to arbitration," C. SuMmers, supra note 17, tend to illustrate the Board's discretionary power as well as the role of politics in the formulation of Board policy. The Board, like many administrative agencies, develops policy through adjudication rather than rulemaking, and, indeed, frequently in its history, Board members have simply overruled the prior policy and begun anew. The history of deferral policy is illustrative of this phenomenon. See infra notes 59-126 and accompanying text.

${ }_{71}$ See United Steelworkers of Am. v. Warrior \& Gulf Navigation Co., 363 U.S. 574, 581 (1960); United Steelworkers of Am. v. American Mfg. Co., 363 U.S. 564, 566 (1960).

${ }_{72}$ See United Steelworkers of Am. v. Enterprise Wheel \& Car Corp., 363 U.S. 593, 596 (1960); United Steelworkers of Am. v. Warrior \& Gulf Navigation Co., 363 U.S. 574, 582 (1960).

7 See C. Summers, supra note 17, at 853 (discussing Barrentine v. ArkansasBest Freight Sys., 450 U.S. 728 (1981).

74 "[T]here is no statutory reason why the Board cannot, in the context of deciding a statutory rights dispute, accept an arbitrator's decision on a related contractual question while refusing to give any deference to the arbitrator's decision on the statutory issue." Comment, supra note 12 , at 743 .

It seems that the Board's decision in Spielberg was an attempt to address the problems the Board felt were raised where an employer's action is alleged to violate both the contract and the statute. The Board was "implicitly attempting to accommodate the tension it erroneously perceived between two statutory provisions, section 10 (a) of the NLRA and section 203(d) of the Labor Management Relations [Taft-Hartley] 
however, allows for such deferral and raises the question of whether the Board has abdicated its statutory obligation to protect individual rights. "Does a completely fair arbitration of the employee's contractual rights give any assurance that the employee's statutory rights have been protected"?75 How appropriate is such a vaguely defined standard as "clearly repugnant" when the contract and the statute may conceivably differ as to acceptable conduct by the employer? ${ }^{76}$

The Spielberg decision not only formed the foundation for Board deferral policy, but also set the tone for the Board's future treatment of the deferral doctrine. Sixteen years after Spielberg, the Board formulated the second branch of its deferral policy in Collyer Insulated Wire, $A$ Gulf $\mathcal{E}$ Western Systems Co. ${ }^{77}$ The General Counsel ${ }^{78}$ charged that

Act (LMRA)." Comment, supra note 12, at 742-43. Section 10(a) deals solely with statutory rights: "[T]he Board is empowered . . . to prevent any person from engaging in any unfair labor practice . . . affecting commerce. This power shall not be affected by any other means of adjustment ... that has been or may be established by agreement, law, or otherwise." National Labor Relations [Wagner] Act § 10(a), 29 U.S.C. $\S 160$ (a) (1982). Conversely, section 203(d) deals with contractual rights. See Comment, supra note 12, at 743; see also Labor Management Relations [Taft-Hartley] Act $\S 203$ (d), 29 U.S.C. § 173(d) (1982). The ultimate question then, is whether the Board should have balanced these two statutory provisions. See Comment, supra note 12 , at 743, 763-65 (arguing that the Board was incorrect in undertaking the process of balancing section 10(a) and 203(d) because the Board has a responsibility to adjudicate statutory disputes, even if such adjudication would disrupt a voluntary contractual agreement).

75 C. SUMMERS, supra note 17 , at 856-57.

${ }^{76}$ See id. The prevailing Board definition of "clearly repugnant" is central to the degree of deference that the Board will be willing to accord to arbitral decisions. In 1978 and 1979 Member Truesdale urged that the "clearly repugnant" to the purposes of the Act standard be modified to require that "the arbitrator's legal conclusions [be] consistent with Board law." Sea-Land Serv., Inc., 240 N.L.R.B. 1146, 1149 (1979) (Truesdale, concurring); see also Kansas City Star Co., 236 N.L.R.B. 866, 867-69 (1978) (Truesdale, concurring). Such a standard would, in effect, give the Board the power to refuse deference in virtually any case in which it disagreed with the result.

Earlier, the Board had interpreted the "clearly repugnant" standard to mean "palpably wrong." See International Harvester Co., 138 N.L.R.B. 923, 928-29 (1962) (case dismissed), enforced sub nom. Ramsey v. NLRB, 327 F.2d 784 (7th Gir.), cert. denied, 377 U.S. 1003 (1964).

In 1984, the Board made clear that it was following the more deferential "palpably wrong" standard:

[D]ifferences, if any, between the contractual and statutory standards of review should be weighed by the Board as part of its determination under the Spielberg standards of whether an award is "clearly repugnant" to the Act. And, with regard to the inquiry into the "clearly repugnant" standard, we would not require an arbitrator's award to be totally consistent with Board precedent. Unless the award is "palpably wrong," i.e., unless the arbitrator's decision is not susceptible to an interpretation consistent with the Act, we will defer.

Olin Corp., 268 N.L.R.B. 573, 574 n.7 (1984) (emphasis added).

72192 N.L.R.B. 837 (1971).

78 The NLRB is actually composed of two distinct branches. The five-member 
the employer had made unilateral changes in wages and conditions of employment in violation of sections 8(a)(5) and 8(a)(1) of the Act. ${ }^{29}$ The case turned on the interpretation of the parties' collective bargaining agreement, which provided for the employer to implement wage adjustments. ${ }^{80}$ The employer argued that the dispute should have been adjudicated in the grievance procedure provided for in the contract. ${ }^{\mathbf{} 1}$ The Board found merit in the employer's contentions "because this dispute in its entirety arises from the contract between the parties"82 and deferred consideration of the dispute pending arbitration. ${ }^{\mathbf{8 3}}$

After engaging in the obligatory salutations to the arbitration process, $^{84}$ the NLRB defended its decision by pointing to the factors that it had considered:

[T]his dispute arises within the confines of a long and productive collective-bargaining relationship. . . . [N]o claim is made of enmity by [the employer] to employees' exercise of protected rights. [The employer] has credibly asserted its willingness to resort to arbitration under a clause providing for arbitration ....

... The contract and its meaning . . . lie at the center of this dispute. ${ }^{85}$

As a result, the Board concluded that the grievance was "eminently well suited to resolution by arbitration."86 It was, as the plural-

Board, appointed by the President with the consent of the Senate for five year terms, performs the agency's adjudicative function, while the office of the General Counsel, with the General Counsel appointed to a four year term under the same procedure, "has authority to investigate charges of unfair labor practices, to decide whether complaints should be issued on the basis of these charges and to direct the prosecution of such complaints." A. Cox, D. BoK, \& R. Gorman, Cases and Materials on LaBOR LAW 104 (1981). The General Counsel also represents the Board in proceedings to revise or enforce its decisions and interprets Board decisions in order to determine how to apply Board law. For a more detailed discussion, see id. at 104-13.

79 Collyer, 192 N.L.R.B. at 837-39.

${ }^{80} I d$. at $837-39$.

81 See id. at 837.

${ }^{82}$ Id.at 839.

8s Id. at 843. The Board retained jurisdiction to entertain a subsequent motion for further consideration if the dispute was not resolved in the grievance procedure, if the dispute was not submitted to arbitration "with reasonable promptness," if the grievance procedures were not fair and regular, or if the result reached in the grievance or arbitration process was repugnant to the Act. Id.

84 "[D]isputes such as these can better be resolved by arbitrators with special skill and experience in deciding matters arising under established bargaining relationships than by the application by this Board of a particular provision of our statute." Id. at 839.

8s Id. at 842 .

so Id. 
ity noted, "the very stuff of labor contract arbitration."87 Ardent dissents by members Fanning and Jenkins ${ }^{88}$ claimed that Collyer redefined Spielberg by mandating "compulsory arbitration." sponse, the plurality suggested that rather than compelling arbitration, Collyer deferral was "merely giving full effect to [the parties'] own voluntary agreements ... rather than permitting such agreements to be sidestepped and permitting the substitution of our processes, a forum not contemplated by their own agreement."80

The Collyer decision, as a case involving only collective rights, clearly reflects the policies underlying the Act and the exhortations of the Steelworkers Trilogy. However, the same Board's decision in $\mathrm{Na}$ tional Radio Company ${ }^{91}$ is more difficult to justify. In National Radio the Board held that it was empowered to defer action with regard to alleged violations of individual rights pending arbitration, provided that "on balance, to do so [would] advance the policies and purposes of the Act."92 The case concerned an allegation that the employer had violated section $8(a)(5)$ by unilaterally instituting a policy whereby union representatives were required to report to their supervisors when leaving designated work areas in order to conduct union grievance business. ${ }^{93}$ This allegation was coupled with a charge that the employer's disciplining of an employee who failed to comply with the reporting requirement was motivated by anti-union animus and thus violated section $8(a)(3) .94$

The Board faced a situation that was at once analogous to and distinct from Collyer. The grievance necessarily required an interpretation of the relevant contract provisions, ${ }^{95}$ an area within the special

o7 Id.

${ }^{83}$ Collyer, 192 N.L.R.B. at 846 (Fanning, dissenting), 850 (Jenkins, dissenting). Fanning and Jenkins not only dissented in Collyer, but continued to dissent "in every subsequent case in which the Board invoked or expanded upon the Collyer principle of deferral to unused arbitral procedures." R. GORMAN, supra note 3, at 752.

89 Collyer, 192 N.L.R.B. at 847.

90 Id. at 842. Collyer presented the ideal situation for deferral: "A Board decision would have required an analysis of contract terms, bargaining history and plant practices-precisely the task normally given to arbitrators, for which the Supreme Court has consistently held them specially qualified." R. Gorman, supra note 3 , at 753 .

91198 N.L.R.B. 527 (1972).

92 Id. at 531 (footnote omitted). Once again, the Board retained jurisdiction to "preserve the right of the Charging Party to seek from . . . [the NLRB] vindication of statutory rights should the arbitration reach a result not tolerable under the statute." Id.

9s See id. at 527.

ot See id. at 530 .

os See id. at 529-30 (The complaint dealt with provisions in the collective bargaining agreement covering the employer's right to establish rules concerning plant operation, the union's right to "free movement" within the plant, whether the disciplinary 
realm of competence of the arbitrator. Nonetheless, the section 8(a)(3) charge required a resolution of factual questions with regard to the presence of anti-union animus. In short, National Radio involved issues concerning both collective and individual rights. ${ }^{96}$ In Collyer, the resolution of the contract dispute also resolved the unfair labor practice issue. ${ }^{97}$ If the employer's activities were permissible under the collective bargaining agreement, its adoption of the procedure without prior bargaining would not be an unfair labor practice because the issue was bargained over when the collective agreement was reached. Conversely, if the contract did not provide for the employer's actions, its refusal to bargain before taking action would be an unfair labor practice: a failure to bargain over terms and conditions of employment. ${ }^{88}$ National Radio is, however, distinguishable from Collyer because there was a "narrow penumbra"99 wherein the reporting procedure might well have been within the employer's rights under the contract, but still a violation of the Act because it was motivated by anti-union animus. ${ }^{100}$

Presumably, the question of anti-union animus is a factual one within the special competence of the NLRB. With this "narrow penumbra" in mind, the Board noted that it would have to be "especially cautious in declining to assert the exclusive jurisdiction" of the NLRB with respect to protecting and remedying alleged violations of section 8. ${ }^{101}$ Nonetheless, the Board extended its deference to the arbitration system, explicitly stating that it had the power to do so and that such deference served the purposes of the NLRA. ${ }^{102}$ Finding the employer's argument that arbitration would lead to a decision that would not be repugnant to the Act to be a "tenable assumption," 103 the Board supported its assertion that the basic considerations underlying Collyer were equally applicable in National Radio: "Here, as [in Collyer], an asserted wrong is remediable in both a statutory and a contractual forum. Both jurisdictions exist by virtue of Congressional action, and our duty to serve the objectives of Congress requires that we seek a rational

action was for just cause, and how these provisions were affected by course of dealing.).

(6ee General Am. Transp. Corp., 228 N.L.R.B. 808, 810-11 (1977) (Murphy, Chairman, concurring).

${ }^{87}$ See 198 N.L.R.B. at 530.

8s See National Labor Relations [Wagner] Act $\S \S 8(\mathrm{a})(5), 9(a), 29$ U.S.C. $\S \S 158(a)(5), 159$ (a) (1982).

"9 National Radio, 198 N.L.R.B. at 530.

100 See id.

${ }^{101} I d$. ("[T]here does exist that possibility that a contractually sound and entirely proper arbitrator's award might fail to dispose of all issues arising under the Act.").

102 Id.

103 Id. at 531. 
accommodation within that duality." whether or not the Board's duty "requires" or even allows it to defer to an arbitrator in cases involving statutory individual rights-rights that Congress charged the Board to protect. The Board, nevertheless, equated its policy of abstention not with abdication but with fostering collective bargaining and industrial self-government. ${ }^{103}$

After the 1976 Presidential election and attendant change in Board membership, members Fanning and Jenkins found themselves either in a majority or a plurality with regard to certain issues before the NLRB. ${ }^{108}$ They took the opportunity to implement as Board policy their long line of dissents on the deferral question. In General American Transportation Corp. ${ }^{107}$ a plurality moved away from Collyer, concluding that the NLRB cannot give up or share its statutory duty to decide unfair labor practice questions:

[W]e believe that the Board has a statutory duty to hear and to dispose of unfair labor practices and that the Board cannot abdicate or avoid its duty by seeking to cede its jurisdiction to private tribunals. . . . Section 10(a) of the Act is explicit that the Board's power to prevent unfair labor practices "shall not be affected by any other means of adjustment ...."108

Additionally, the plurality emphasized that section $8(a)$ (3) protected individual rights, as compared to union or group rights. ${ }^{100}$ " $[\mathrm{W}]$ here the charging party is an individual discriminatee seeking to enforce his individual rights," deferral would destroy the voluntary nature of arbitra-

104 Id. (emphasis added) (footnote omitted).

105 See id. at 531-32. The Board found that "wholly aside from considerations arising from the increasing caseload before this five-man Board . . . the purposes of the Act are well served by encouraging the parties to those contracts to resolve their disputes without government intervention." Id. (footnote omitted).

Members Fanning and Jenkins, in their dissent, asserted that by deferring to arbitration, the Board was engaging in "subcontracting to a private tribunal the determination of whether [rights conferred and guaranteed solely by the] statute" were violated. Id. at 533 (Fanning and Jenkins, dissenting). "Such action mocks the statute and the reason for this Board's existence." Id.

${ }_{106}$ In 1977 the Board consisted of Members Fanning and Jenkins in one block, and Members Panello and Walther in another. Chairman Murphy provided the "swing" vote on the issue of whether or not to defer. Although she gave Fanning and Jenkins her vote in General Am. Transp. Corp., 228 N.L.R.B. 808 (1977), she did not agree with their general position that the Board lacks the statutory authority to defer any unfair labor practice allegation. See infra notes 112-16 and accompanying text.

107228 N.L.R.B. 808 (1977).

108 Id. (footnote omitted) (quoting National Labor Relations [Wagner] Act $\S 10(a), 29$ U.S.C. $\S 160(a)(1982))$.

${ }^{100} 228$ N.L.R.B. at 808. 
tion, the main reason for Collyer deferral, by forcing employees into the arbitral process for a resolution of their claims. ${ }^{110}$ By invoking Board processes, the charging party was acting upon the conclusion that arbitration would be futile. 11

The Board's opinion in General American Transportation, while significant, was perhaps less noteworthy than the concurrence of Chairman Murphy who provided the "swing vote" and thus actually defined the Board's holding. ${ }^{112}$ The Chairman agreed with the Board's unwillingness to defer in General American Transportation, but could not agree with the broad holding that the Board lacked the statutory authority to defer any unfair labor practice complaint to arbitration. ${ }^{113}$ Unlike members Fanning and Jenkins, the Chairman analyzed the deferral controversy by distinguishing between unfair labor practices growing out of differences between the parties as to the "interpretation and/or application of their collective-bargaining agreement"- an area appropriate for deferral, and unfair labor practices involving alleged

110 See id. at 808-09.

111 See id. at 808.

118 See supra note 107. Despite her disagreement with a broad reading of General Am. Transp., Chairman Murphy nonetheless agreed with Members Fanning and Jenkins that deferral was inappropriate based on the facts of the case. She felt, however, that deferral was appropriate in Roy Robinson Chevrolet, 228 N.L.R.B. 828 (1977), decided on the same day. The Chairman, again concurring, agreed with Members Panello and Walther that the facts of Roy Robinson Cheorolet warranted deferral:

In view of the massive judicial approval of Collyer by the courts . . . Collyer must be accepted as law binding upon the Board under American legal tradition, notwithstanding the fact that some individual Board members may not agree with it. Board members may disagree with its application, but at this point in time they are not free, we believe, to treat the doctrine as a nullity."

Id. at 829. Thus, because on the facts of the case resolution of the contract interpretation issue would necessarily resolve the $8(a)(1)$ and $8(a)(5)$ allegations, the Board opted to defer. $I d$. ("TT]he purposes of the Act will best be discharged by deferring the issue in dispute to the grievance-arbitration procedure which the parties themselves have created ....."). The Chairman expressed her agreement with Collyer's premise that the NLRB had the discretionary authority to defer to the grievance-arbitration procedure of the parties when issues involving "purely the interpretation of the rights and obligations of the parties under a collective-bargaining agreement" were presented. Id. at 831. The Chairman could not agree, however, that the Board should exercise its discretion to defer to the parties' processes when violations of section $8(a)(1)$ and $8(a)(3)$ or section $8(\mathrm{~b})(1)(\mathrm{A})$ and $8(\mathrm{a})(2)$ were alleged. Id.

The Chairman's concurrences in General Am. Transp. and Roy Robinson Chevrolet are consistent because she refuses to consider section $8(\mathrm{a})(1)$ claims as independent of the underlying charge of either section $8(a)(3)$ or $8(a)(5)$. Given section 8(a)(1)'s availability as a catch-all charge, the Chairman's analysis is sound because failure to attach section $8(a)(1)$ to the other substantive charge would allow the employee to avoid the contract-grievance procedure in pure contract interpretation cases, namely those involving section $8(a)(5)$ claims.

${ }_{11}$ See General Am. Transp., 228 N.L.R.B. at 810 (Murphy, Chairman, concurring). 
interference with section 7 rights-an area where deferral would be inappropriate. ${ }^{114}$ In the former case, the dispute is principally between the contracting parties, while in the latter case, the dispute is between the employee and either the employer or the union. ${ }^{115}$ Because the resolution of the contract issue would not necessarily dispose of the unfair labor practice claim in the latter case, and because arbitration is not suitable for the resolution of alleged violations of individual rights, the Chairman urged the reversal of National Radio while noting her continuing approval of Collyer. ${ }^{116}$

As in 1976, the 1980 presidential election brought a new administration to Washington-an administration that appointed Board Members with a different philosophy of labor relations. In January 1984, the Board overhauled both branches of its deferral policy. In Olin Corp. ${ }^{117}$ the Board "clarified" the Spielberg standards for deferral to arbitration awards. The NLRB will now find that an arbitrator has decided the unfair labor practice claim if "(1) the contractual issue is factually parallel to the unfair labor practice issue, and (2) the arbitrator was presented generally with the facts relevant to resolving the unfair labor practice."118 Any discrepancy between the contractual and statutory standards is to be considered by the Board when it makes its Spielberg determination of whether the decision is "clearly repugnant" to the NLRA. ${ }^{110}$ The decision of the arbitrator need not be consistent with Board precedent; rather, the NLRB will defer unless the arbitrator's decision is " 'palpably wrong, i.e., unless the arbitrator's decision is not susceptible to an interpretation consistent with the Act."120

Member Zimmerman's dissent questioned the majority's logic:

If the contractual issue is factually parallel to the unfair labor practice issue, then how can one possibly prove that the facts relevant to resolving the unfair labor practice issue have not been presented to the arbitrator unless one proves the absurdity that even the facts relevant to the contract issue were not presented?"121

114 Id. at 811-13 (Murphy, Chairman, concurring).

118 Id. at 813 (Murphy, Chairman, concurring). "By the same token, an allegation that an employee's statutory rights have been invaded by the employer, the union, or by both ought not to be adjudicated by the very party or parties charged with the wrongdoing." Id. at 812 (Murphy, Chairman, concurring).

${ }_{116}$ See id. at 811 (Murphy, Chairman, concurring).

117268 N.L.R.B. 573 (1984).

118 Id. at 574 (footnote omitted).

119 Id.

120 Id.

132 Id. at 579 (Zimmerman, dissenting). 
Zimmerman recognized that the Board was indulging in a presumption that any evidence of anti-union animus will be presented "unless the General Counsel can prove that there is no factual parallel between the issues. The more broadly the Board construes the notion of factual parallelism, the more difficult the General Counsel's task becomes."122

On the same day that it issued its decision in Olin Corp., the Board announced its ruling in United Technologies Corp. ${ }^{123}$ United Technologies overruled General American Transportation, leaving only Collyer as modified by National Radio. ${ }^{124}$ As the Board stated, "Contrary to the notion of the majority in General American Transportation, deferral is not akin to abdication. It is merely the prudent exercise of restraint, a postponement of the use of the Board's processes to give the parties' own dispute resolution machinery a chance to succeed."125

Member Zimmerman, also dissenting in United Technologies, disagreed with the return to an expansive deferral policy, finding it to have four fundamental flaws:

First, a union, without breaching its duty of fair representation, might not vigorously support an employee's claim . . . [because] in balancing individual and collective interests, [the union] might trade off an employee's statutory right in favor of some other benefits for employees in the bargaining unit as a whole. Second, because arbitrators' competency is primarily in "the law of the shop, not the law of the land," they may lack the competency to resolve the statutory issue[s] involved in the dispute. Third, even if the arbitrator is conversant with the Act, he is limited to determining the dispute in accordance with the parties' intent under the collective-bargaining agreement. Finally, because the arbitrator's function is to effectuate the parties' intent rather than enforce the Act, he may issue a ruling that is inimical to the public policies underlying the Act, thereby depriving an employee of his protected statutory rights. ${ }^{126}$

\footnotetext{
192 Id. (footnote omitted).

128268 N.L.R.B. 557 (1984).

124 See $i d$. at 560 .

${ }^{125}$ Id. The Board erred in referring to a majority opinion. General Am. Transp. was decided by a plurality of Fanning and Jenkins, with Murphy providing the swing vote. Panello and Walther dissented.

${ }^{128}$ Id. at 563-64 (Zimmerman, dissenting) (footnotes omitted) (quoting Barrentine v. Arkansas-Best Freight Sys., 450 U.S. 728, 743 (1981)).
} 


\section{Deferral Policy and the Joint Committee-The BOARD, THE TEAMSTERS, AND THE INDIVIDUAL}

Since its 1961 decision in Denver-Chicago Trucking Co., ${ }^{127}$ the Board has deferred to a joint grievance committee decision if the decision withstands analysis under the Spielberg Manufacturing Co. ${ }^{128}$ branch of its deferral policy. In Denver-Chicago Trucking, the Board was faced squarely with the issue of whether the joint grievance committee proceedings met the Spielberg standards of fairness and regularity. ${ }^{128}$ In finding that the Spielberg standards were met, the Board focused on procedural fairness ${ }^{130}$ and did not reach the question of whether the joint grievance committee system can adequately protect the rights of the individual. The Board's failure to look beyond procedure is troubling because procedural guarantees will not protect the individual employee if the joint committees are not competent to adjudicate or cannot fairly decide the statutory issue. This lack of concern with the substantive protection of individual rights has plagued both the Board and the courts in their considerations of cases involving the Teamster grievance system.

The recent decision of Carolina Freight Carriers Corp. ${ }^{131}$ followed the 1984 modifications in Board deferral policy ${ }^{\mathbf{1 3 2}}$ and illustrates deferral in the Teamster context. The General Counsel contended that the employer violated section $8(a)(1)^{133}$ of the Act by punishing employees for their concerted activity of stopping their vehicles at the noon hour to update their logs and recording that time as "on-duty not driv-

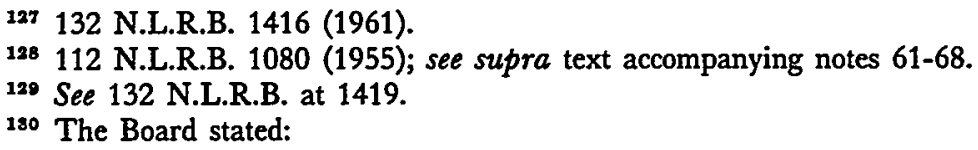

[F]ailure to adopt the decision of the Joint Committee would imply an obligation to fix standards of formality in procedure on the part of grievance and arbitration panels which must be met before their awards could receive endorsement. We consider it enough under Spielberg if the procedures adopted meet normal standards as to sufficiency, fairness, and regularity. ... Where, as here, the parties have found that the machinery which they have created for the amicable resolution of their disputes has adequately served its purpose, we shall accept such a resolution absent evidence of irregularity, collusion, or inadequate provisions for the taking of testimony.

132 N.L.R.B. at 1421. In a footnote, the Board stipulated that it did not find it necessary to have a public member sit on grievance panels. Id. at 1421 n.6.

131 No. JD-91-84 (NLRB Div. of Judges, Socoloff, A.L.J., Mar. 12, 1984).

132 See supra notes $117-126$ and accompanying text. (1982).

${ }^{188}$ National Labor Relations [Wagner] Act § 8(a)(1), 29 U.S.C. § 158(a)(1) 
ing."134 The logs are required by the Department of Transportation. ${ }^{\mathbf{1 3 5}}$ The General Counsel also argued that the employer violated section $8(a)(3)^{136}$ by discriminating against an employee involved in the logging activity in the assignment of requested runs. ${ }^{137}$ The charging parties had first filed contractual grievances with the Joint Maryland District of Columbia Area Committee. ${ }^{138}$ The grievances were denied, and subsequently the employees sought relief before the NLRB. ${ }^{139}$

As the Administrative Law Judge (A.L.J.) noted, under Olin Corp. ${ }^{140}$ the party seeking to have the Board reject deferral must show that the standards for deferral have not been met. ${ }^{141}$ With regards to the $8(a)(1)$ violation, the A.L.J. found the record silent as to whether the joint committee was presented with or considered evidence concerning the concerted nature of the activities, ${ }^{142}$ an essential requirement for the statutory claim. ${ }^{143} \mathrm{He}$ found, nevertheless, that the General Counsel "failed to establish that, in fact, evidence of the concerted nature of the employees' activities was not before the Committee."144 Thus, following Olin Corp., the A.L.J. did not consider the issue on its merits, but rather deferred to the decision of the grievance committee. ${ }^{14 \delta}$

Concerning the $8(a)(3)$ issue, the A.L.J. found that the General Counsel's contention of discrimination in assignments was "based upon the substantial credited record evidence ... that [the employer] harbored ill will toward that employee because of his union activities . . . "146 Despite this finding, the A.L.J. reasoned that since the section $8(a)(3)$ charges were "cognizable under the grievance-arbitration provisions of the parties' collective-bargaining agreement,"147 and the employer had expressed a willingness to arbitrate the dispute, United Technologies Corp. ${ }^{148}$ required deferral. ${ }^{149}$ Therefore, despite

134 Carolina Freight, slip op. at 3.

1 see id.

(1982).

1s6 National Labor Relations [Wagner] Act $\S 8(a)(3), 29$ U.S.C. § 158(a)(3)

${ }_{137}$ See Carolina Freight, slip op. at 3.

138 Id. at 4.

${ }^{239}$ See id. The 1982 decisions issued by the Joint Maryland District of Columbia

Area Committee denied the grievances summarily, merely stating that "based upon the facts presented the claim of the Union is denied." Id.

${ }_{140} 268$ N.L.R.B. 573 (1984).

141 See Carolina Freight, slip op. at 6 (following Olin Corp., 268 N.L.R.B. 573,

574 (1984)); supra text accompanying notes 118-21 (standard for deference).

142 See Carolina Freight, slip op. at 4.

143 See id. at 6.

144 Id.

${ }_{145}$ See id.

148 Id. at 4-5.

147 Id. at 6.

148268 N.L.R.B. 557 (1984).

140 See Carolina Freight, slip op. at 6-7. 
the fact that the individual employees requested a Board decision on the dispute, the collective bargaining agreement took precedence in determining the proper avenue for dispute resolution.

Carolina Freight highlights the problems that may arise with deferral in the Teamster context and emphasizes the lack of analysis in the Board's application of its deferral policy to the Teamster committees. The Supreme Court, like the NLRB, has failed to engage in a meaningful inquiry into the Teamster system and has been content to regard the joint committees as arbitral bodies, or at least as their functional equivalent. ${ }^{180}$ By deferring to Teamster joint grievance committee decisions absent extreme circumstances, the NLRB and the courts have avoided resolving the issue of whether the Teamster system is the type of dispute resolution process envisioned in and endorsed by the Taft-Hartley Act ${ }^{161}$ and the Steelworkers Trilogy. ${ }^{162}$ Examining

150 There is some debate over exactly how enthusiastically the Supreme Court has embraced the joint grievance committee system and to what degree the Court has actually interpreted the joint committee process as the equivalent of arbitration. In General Drivers v. Riss \& Co., 372 U.S. 517 (1963), the Court did not directly hold that the Teamster grievance procedure was equivalent to neutral arbitration. Rather, the Court simply reasoned that because the parties had agreed contractually to be bound by the process, the employer could not repudiate it. See id. at 519; Feller, Arbitration Without Neutrals: Joint Committees and Boards, 37 Proc. NAT'L ACAD. ARB. [ARBITRATION 1984] 106, 110 (1984).

Nonetheless, the Teamsters and some circuits rely upon Riss to support the claim that the Teamster committees are on the same level as neutral arbitrators. $C f$. Morris v. Werner-Continental, Inc., 466 F.2d 1185 (6th Cir. 1972), cert. denied, 411 U.S. 965 (1973); Price v. International Bd. of Teamsters, 457 F.2d 605, 611 (3d Cir. 1972). Feller notes that the Court

has treated joint committee decisions as arbitration although in no case in which it did so was the question argued [Riss; United Parcel Serv. v. Mitchell, 451 U.S. 56 (1981); Hines v. Anchor Motor Freight, 424 U.S. 554 (1976); Humphrey v. Moore, 375 U.S. 335 (1964)] and in the only case in which the question was squarely put before it, the Court did not explicitly affirm its prior language [DelCostello v. International Bd. of Teamsters, 462 U.S. 451 (1983)].

Feller, supra, at 115.

The circuit courts do not agree on the degree of deference to be accorded the joint committees. Some circuits have accorded the grievance committees a great deal of deference. See, e.g., Morris, 466 F.2d at 1190-91 ("[S]o long as there is an absence of fraud or bad faith or demonstrated bias or collusion, the decision by the arbitrators, or here, the Joint Committee, is final and binding and courts are generally powerless to interfere."); Harris v. Chemical Leaman Tank Lines, 437 F.2d 167, 171 (5th Cir. 1971) (holding that an employee who has exhausted grievance procedures is ordinarily bound by a resulting adverse decision which is final and binding). Other circuits have been less deferential. See, e.g., Stephenson v. NLRB, 550 F.2d 535, 537 (9th Cir. 1977) (" $A$ priori, when it is impossible to determine what issues the arbitration panel considered, or if the arbitration panel has not considered the statutory issue fairly and consistently with the precepts and purposes of the Act, then the Board should ... not defer.").

${ }^{251}$ Labor Management Relations [Taft-Hartley] Act § 203(d), 29 U.S.C. § 173(d) (1982).

162 United Steelworkers of Am. v. Enterprise Wheel \& Gar Corp., 363 U.S. 593 
whether the committees are truly arbitration or its equivalent will reveal the flaws in the policy of deferring to the committees in cases involving individual rights.

The fundamental issue in the debate over the appropriate role of the joint committee system is "whether a union should be permitted to dispose of individuals' grievances in a power context for the best interest of the organization as a whole, or whether it should be required to obtain the best possible settlement for the individual involved, regardless of the impact on the whole."153 Indeed, the major criticism of the Teamster joint grievance committee system is its potential for "horsetrading:"154 the sacrifice of the interests of the individual for the "good" of the union in the aggregate. While some possibility for "horsetrading" exists in virtually every union grievance procedure, the Teamster system "is structured so as to insure maximization and exploitation of opportunities for wheeling and dealing."1ss The very foundation of the system is a variation of "horsetrading." Since the resolution of the grievance by definition requires the union to vote with management in order to deny the claim, it is clear to both sides from the outset that bargaining will resolve the dispute. Rather than any sort of neutral adjudication on the merits, the decision amounts to either union agreement or disagreement with the basic charge that the management violated the collective bargaining contract. If the grievance is at best tenuous, the union's bargain is a vote to deny it, thus preserving rapport with the employer. If the grievance has merit or, in the eyes of a cynic, if it could potentially benefit the whole of the union's membership, the union can attempt to exact a price by voting against management.

Possibilities of collusion between the union and the employer are real, especially if the employee's interest diverges from that of the union. ${ }^{108}$ One of the dangers inherent in this system is "the ease with which it may be used as a tool for disciplining union members."157 The individual employee has little recourse in cases of less than flagrant

(1960); United Steelworkers of Am. v. Warrior \& Gulf Navigation Co., 363 U.S. 574 (1960); United Steelworkers of Am. v. American Mfg. Co., 363 U.S. 564 (1960).

183 Azoff, supra note 20, at 329 (footnote omitted).

104 See id. at 328; Summers, The Individual Employee's Rights Under the Collective Agreement: What Constitutes Fair Representation?, 126 U. PA. L. REv. 251, 27072 (1977); Tobias, Individual Employee Suits for Breach of the Labor Agreement and the Union's Duty of Fair Representation, 5 U. ToL. L. REV. 514, 543 (1974).

185 Azoff, supra note 20, at 328-29.

${ }^{156}$ See id. at 329.

${ }^{157} I d$. at 336. 
collusion or bad faith. ${ }^{158}$ While under United Technologies Corp. ${ }^{159}$ the Board will not defer if the interests of the union are adverse to those of the charging party, ${ }^{100}$ that promise is of little solace to the discharged employee who, rather than merely asserting that the union was unfair, must show evidence of bias by the union toward the grievant. ${ }^{161}$ Furthermore, even if the employee is successful in proving union bias, she may still be left without a remedy. Although the Board will not defer to the committee decision, even the slightest deviation from the contract may give the employer "just cause" for the discharge. Thus no unfair labor practice will have been committed, and there is no wrong to remedy. ${ }^{162}$ The pressure of many grievances requires the committees to move quickly. ${ }^{163}$ Because joint committees give no reasons for their decisions, "there is nothing which can be reviewed in an action to vacate [a] decision."164 The informality of the process leads to less than ardent argument on behalf of the grievant, ${ }^{165}$ and to abuses in the process. ${ }^{168}$

${ }^{288}$ See id. at 336-37.

169268 N.L.R.B. 557 (1984).

$100 \mathrm{Id}$. at 560 .

101 See Azoff, supra note 20, at 337 (discussing Roadway Express, Inc. 145 N.L.R.B. 513, 515 (1965)).

${ }_{102}$ See Azoff, supra note 20 , at 336-37.

183 See Tobias, supra note 154, at 542 ("The joint committee hears scores of complicated cases on the same day. To resolve a case, both the company and the union members must reach agreement. This requirement, coupled with the heavy docket, encourages the trading of one case against another. Hearings are short in duration.").

164 Petition for Certiorari at 10 (footnote omitted), Early v. Eastern Transfer, 699 F.2d 552 (1st Cir.), cert. denied, 464 U.S. 824 (1983).

${ }_{185}$ The employee's problem is exacerbated by the evidentiary problems present in fair representation suits under section 301 of the Taft-Hartley Act. Labor Management Relations [Taft-Hartley] Act § 301, 29 U.S.C. § 185 (1976). See Azoff, supra note 20, at 350 ("In most cases, it is an almost impossible evidentiary problem to clearly show animus or bad faith even if the court is willing to examine the committee's interpretation of a contract to see if it is so unreasonable as to manifest bad faith." (footnote omitted)).

${ }^{166}$ In Roberson v. Allied Delivery Sys., No. C81-1982 (N.D. Ohio, complaint filed Oct. 2, 1981, case settled and dismissed without prejudice, Oct. 28, 1983), a suit for breach of fair representation under section 301, plaintiff alleged that the Teamsters breached their duty by allowing certain procedural irregularities to pass without comment during his hearing. At a hearing before the Ohio Joint Committee, plaintiff was berated by the President of the Ohio Teamsters Conference and the Vice President of the International Brotherhood of Teamsters whose presence plaintiff alleged violated Joint State Committee Rule 4(c) which permits only panel members to speak. Memorandum in Opposition to Motion for Summary Judgment or Remand of Defendant, Truck Drivers Union Local 407 at $4-5$, Roberson. Plaintiff's affidavit was more explicit:

After both sides had pretty much presented their cases, Mr. Presser spoke. $\mathrm{He}$ berated me and my business agent. He called my grievance "the worst piece of shit I've ever heard." He told me "You're out!" He called me a "trouble-maker." No one objected to nor challenged Mr. Presser's remarks. No one sought to rebut his remarks. No one sought to have $\mathrm{Mr}$. 
Union and management representatives may be concerned with other matters affecting their collective bargaining position. "Both union and employer panel members often have fixed opinions concerning the subject matter of the dispute, based not only upon their friendships and relationships with the litigants, but also upon prior knowledge of the case and upon their knowledge of similar controversies involving their own unions or companies."167 This knowledge of the "law of the shop" illustrates the virtue of the joint committee system in contract interpretation cases, while it poignantly displays the difficulties that an individual faces in pursuing her statutory claim.

By definition, claims of violations of individual rights guaranteed under the NLRA will involve a charge that either the employer or the union has discriminated. In either case, the alleged violator sits in judgment. As such, the employee may proceed under the contract "just cause" standard rather than alleging discrimination, so as not to "offend" members of the joint committee. ${ }^{188}$ As the dissent in Olin Corp. notes, the Board will presume that the arbitrator has been presented generally with the facts necessary to resolve the unfair labor practice issue. ${ }^{169}$ The Board's position, as interpreted by the General Counsel, is that the Board will defer if the grievance alleges that the discharge was not for "just cause," since the arbitrator will be analyzing whether the contractual standard of "just cause" is reached, and that analysis would be factually parallel to that of the statutory issue. If, however, the grievance merely alleged that the employee was innocent or did not deserve the discharge, the analysis would not be factually parallel and the Board would therefore not defer. ${ }^{170}$

The Board's deferral policy puts a grievant who claims both statutory and contractual violations in an awkward position. Olin requires that the party seeking nondeferral prove that "one or more of the Spielberg-Olin standards has not been met." ${ }^{\text {"171 }}$ Given the lack of a re-

Presser's remarks stricken from the record. No one challenged $\mathrm{Mr}$.

Presser's right to speak.

Affidavit of Gregory Roberson at 2, Roberson. Needless to say, plaintiff's grievance was denied. Memorandum in Opposition to Motion for Summary Judgment at 5, Roberson.

187 Tobias, supra note 154 , at 542.

${ }_{103}$ See Mason \& Dixon Lines, 237 N.L.R.B. 6, 12 (1978).

${ }^{169}$ Olin Corp., 268 N.L.R.B. 573, 579 (1984) (Zimmerman, dissenting) ("In reality the majority's new test involves only one step. It will presume that an arbitrator has considered both contract and unfair labor practice issues unless the General Counsel can prove that there is no factual parallel between the issues.").

170 Office of the General Gounsel, Memorandum GC 84-10, Guideline Memorandum Concerning Olin Corp., Daily Labor Report (BNA) (June 26, 1984) at C-9. 17I Id. at C-9 to C-10. 
corded decision in the joint committee process, this is a difficult burden to meet. Thus, the charging party is caught in a Catch-22 situation. If she raises the issue before the joint committee and loses, the Board will defer to the decision. Conversely, if she fails to raise the issue so as to avoid antagonizing committee members, she may lose before the committee and find herself without proof that the unfair labor practice issue was not before the joint panel.

Given the difficulties with the Teamster system in the area of individual rights, this Comment proposes that the Board should develop a separate policy applicable to alleged violations of individual rights. The beauty of the Teamster system is that it is well suited to resolve collective disputes. Yet in cases involving violations of individual rights, the Board's broad deference to joint committee decisions without any real inquiry into the substance of the proceedings ignores the statutory protections for the individual that Congress explicitly included in the NLRA.

To achieve this selective deferral, the Board should develop guidelines for the thorough review of joint committee decisions. Careful review of the committee decision by the Board could clearly define any statutory rights issues. Additionally, the joint committee will be able to weed out spurious statutory claims. ${ }^{172}$ Before the joint committee will be of any use to the Board, however, the committees must develop procedures to record decisions. This would lead to a more complete and better reasoned consideration of the collective issues and would promote efficiency as the committee record could be used to present the facts of the dispute to the Board.

The General Counsel, in a recent interpretation of the Board's deferral policy, limits deferral to situations where the union has sincerely processed the grievance. ${ }^{173}$ This restriction indicates that the General Counsel has recognized that some union grievance procedures do not adequately protect the individual employee. It is now up to the Board to recognize that the Teamster system is such a procedure and does not merit deferral.

\section{CONCLUSION}

In part, the Teamster joint grievance committee system is an extension of the collective bargaining process. Management and the union

172 See Comment, supra note 12 at 768.

173 Office of the General Counsel, Memorandum GC 84-5, Guideline Memorandum Concerning United Technologies Corp., Daily Labor Report (BNA) (Mar. 19, 1984) at C-8. 
bargain over whether the activity which caused the grievance violated the contract, thereby institutionalizing the Supreme Court's conception of grievance and arbitration procedure as "a part of the continuous collective bargaining process."174 As such, the system promotes the collective interests of the union and provides a mechanism through which the union and management can settle their differences in interpretation of the collective bargaining agreement. In practice, the system does not protect the individual rights of the employees.

The Board's application of its deferral policy in the Teamster cases is troublesome for two reasons. First, the Board is failing to acknowledge that the joint grievance system is not truly "arbitration" but instead is a process where interested parties are making decisions, conflicts of interests are apparent, and the fair representation of grievants is questionable. Second, the committee's expertise, like the arbitrator's, is in the law of the shop; its function as interpreter of the collective bargaining agreement does not prepare it to determine the presence or absence of the discrimination prohibited by the Act. Rather, the Board is the expert at statutory interpretation.

Before the landmark Collyer decision, Member Jenkins, an outspoken critic of excessive Board deferral, noted his dissatisfaction with the joint committee process. Unfortunately, some fifteen years later, his concerns are still relevant:

Whatever result such a committee of the protagonists might reach, it is in part the product of economic power, adjustment with an eye on other disputes or differences between them or on their future bargaining positions, and other considerations unrelated to the merits of the particular claim before the Committee. ${ }^{175}$

The Board and the courts must realize that the joint committee is a negotiating instrument, aimed at cementing the collective strength of the union at the expense of the individual. The fact that the Teamster process is successful in resolving contractual disputes should not obscure inquiry into its ability to justly adjudicate claims made by individual employees.

United Steelworkers of Am. v. Warrior \& Gulf Navigation Co., 363 U.S. 574, 176 Terminal Transp. Co., 185 N.L.R.B. 672, 675 (1970). 